\title{
Development and sensory evaluation of products containing the Brazilian Savannah fruits araticum (Annona crassiflora Mart.) and cagaita (Eugenia dysenterica Mart.)
}

\author{
Desenvolvimento e avaliação sensorial de produtos com frutos do Cerrado brasileiro \\ araticum (Annona crassiflora Mart.) e cagaita (Eugenia dysenterica Mart.)
}

\author{
Henrique Silvano Arruda ${ }^{1 *}$, Diego Alvarenga Botrel ${ }^{2}$, Regiane Victória de Barros Fernandes², \\ Martha Elisa Ferreira de Almeida ${ }^{3}$ \\ 'Universidade Estadual de Campinas (UNICAMP), Faculdade de Engenharia de Alimentos, Departamento de Ciência de Alimentos, Campinas/SP - Brazil \\ 2Universidade Federal de Lavras (UFLA), Departamento de Ciência dos Alimentos, Lavras/MG - Brazil \\ ${ }^{3}$ Universidade Federal de Viçosa (UFV), Instituto de Ciências Biológicas e da Saúde, Campus de Rio Paranaíba, Rio Paranaíba/MG - Brazil
}

\section{${ }^{*}$ Corresponding Author}

Henrique Silvano Arruda, Universidade Estadual de Campinas (UNICAMP), Faculdade de Engenharia de Alimentos, Departamento de Ciência de Alimentos, Rua Monteiro Lobato, 80, CEP: 13083-862, Campinas/SP - Brazil, e-mail: hsilvanoarruda@gmail.com

Cite as: Development and sensory evaluation of products containing the Brazilian Savannah fruits araticum (Annona crassiflora Mart.) and cagaita (Eugenia dysenterica Mart.). Braz. J. Food Technol., v. 19, e2015105, 2016.

Received: Dec. 15, 2015; Accepted: Aug. 11, 2016

\section{Summary}

The objective of this study was to use the pulp of the Brazilian Savannah fruits araticum and cagaita to develop new products, and to evaluate their sensory acceptance by children from 7 to 9 years of age. The products developed were: three milk caramel formulations: DP (standard), DA (araticum pulp) and DB (araticum pulp and grated coconut); three cagaita refresher formulations: RP (cagaita pulp), RA (cagaita pulp and orange juice) and RB (cagaita pulp and carrot juice); and a cagaita jam formulation. It was found that the three formulations of milk caramels were equally accepted $(p>0.05)$, whereas the RA refresher was more accepted $(p<0.05)$ than the others (RP and RB). In addition, the cagaita jam received high sensory acceptance scores. All the products developed were well accepted since their acceptability indexes were greater than $70 \%$. There was no influence $(p>0.05)$ of gender on the sensory acceptability of the products evaluated. It was concluded that the products developed showed good acceptability from a sensory point of view, which suggests high market potential.

Keywords: Annona crassiflora; Eugenia dysenterica; Milk caramels; Refresher; Jam; Children.

\section{Resumo}

O objetivo deste estudo foi utilizar a polpa dos frutos do Cerrado brasileiro araticum e cagaita para desenvolver novos produtos e avaliar a aceitabilidade sensorial por crianças de 7 a 9 anos de idade. Os produtos desenvolvidos foram: três formulações de doce de leite: DP (padrão), DA (com polpa de araticum) e DB (com polpa de araticum e coco ralado); três formulações de refresco de cagaita: RP (polpa de cagaita), RA (polpa de cagaita e suco de laranja) e RB (polpa de cagaita e suco de cenoura); e uma formulação de geleia de cagaita. Verificou-se que as três formulações de doce de leite foram igualmente aceitas $(p>0,05)$, enquanto o refresco RA foi mais aceito $(p<0,05)$ que os demais (RP e RB). Além disso, a geleia de cagaita apresentou elevados escores de aceitação sensorial. Todos os produtos desenvolvidos foram bem aceitos, uma vez que seus índices de aceitabilidade foram maiores que $70 \%$. Não houve influência $(p>0,05)$ do gênero sobre a aceitabilidade sensorial dos produtos avaliados. Conclui-se que os produtos desenvolvidos apresentaram boa aceitabilidade do ponto de vista sensorial, o que sugere um elevado potencial de mercado.

Palavras-chave: Annona crassiflora; Eugenia dysenterica; Doce de leite; Refresco; Geleia; Crianças. 
Arruda, H. S. et al.

\section{Introduction}

The Savannah biome is the most characteristic of Brazil, covering 13 states and the Federal District and occupying about 2 million $\mathrm{km}^{2}$, which represents 25\% of the country. The Savannah contains major sources of natural biological resources, with diverse flora and fauna, and is considered the second largest biome in the country, surpassed only by the Amazon Forest. The species include about $30 \%$ of the total existing in Brazil, but knowledge of its plants and animals is still scarce (ARRUDA; ALMEIDA, 2015; SILVA et al., 2008b).

The Savannah fruits have been used since the early days of occupation of the region, and their inclusion in cooking has attracted the attention of various segments of society, such as farmers, industry, research institutions and health agencies. Currently, more than 58 species of native Savannah fruits used by the population have shown high nutritional value besides offering sensory attractions, such as unique and intense colours, flavours and aromas (ARRUDA et al., 2012). Although these fruits present many sensory properties, they have not been systematically studied and are not commercially available. These unique sensory characteristics make the Savannah fruits very suitable for use as food or as natural food additives. In addition, many plants used as typical foods have caught the attention of consumers and are being welcomed onto the world market as functional and nutraceutical foods (FINCO et al., 2012).

Many Savannah fruit species are potential sources for economic exploitation, as they have high levels of sugars, proteins, fatty acids, minerals, carotenoids and vitamins (especially of the B complex) (SILVA et al., 2008a). Although showing great potential, they have mostly been exploited in an extractivist manner, since the fruits are not well-known or appreciated outside the Savannah region (FINCO et al., 2012). Thus, the regional consumption of food with potential nutritive and functional value can be encouraged through the use of post-harvest technologies which increase the shelf life of these fruits, providing new products and generating added value (CAMPOS et al., 2012).

The economic exploitation of the Savannah has been made possible by the research and development of technologies under this ecosystem. In addition, there has been a special focus on the best way to use native fruits in order to preserve and use them in a rational and sustainable manner (QUEIROZ, 2011). Among the numerous native Savannah fruits with potential for use in the development of new products, araticum (Annona crassiflora Mart.) and cagaita (Eugenia dysenterica Mart.) can be highlighted, since they have acceptable sensory characteristics as well as significant nutritional and functional potential.

The araticum and cagaita fruits showed good sensory acceptance by children, as previously reported by Arruda et al. (2015). Furthermore, some recent studies have shown that these fruits are rich in nutrients and bioactive compounds. According to Cardoso et al. (2013), $100 \mathrm{~g}$ of araticum pulp contains $1.52 \mathrm{~g}$ proteins, $3.50 \mathrm{~g}$ lipids, $14.39 \mathrm{~g}$ carbohydrates, $0.47 \mathrm{~g}$ ash, $95.12 \mathrm{kcal}$, $6.80 \mathrm{~g}$ dietary fibre, $4.98 \mathrm{mg}$ carotenoids, $288.79 \mathrm{RAE}$ (Retinol Activity Equivalent) (vitamin A), $5.23 \mathrm{mg}$ ascorbic acid, $494.04 \mathrm{mg}$ vitamin $\mathrm{E}$ and $27.36 \mathrm{mg}$ folates, besides a total titratable acidity of $0.54 \%$, total soluble solids of $22.54{ }^{\circ} \mathrm{Brix}$ and a pH value of 4.89 . On the other hand, $100 \mathrm{~g}$ of cagaita pulp contains $0.63 \mathrm{~g}$ proteins, $0.57 \mathrm{~g}$ lipids, $5.54 \mathrm{~g}$ carbohydrates, $0.18 \mathrm{~g}$ ash, $29.83 \mathrm{kcal}, 1.51 \mathrm{~g}$ dietary fibre, $0.77 \mathrm{mg}$ carotenoids, 45.53 RAE (vitamin A), $34.11 \mathrm{mg}$ ascorbic acid and $25.74 \mathrm{mg}$ folates, besides a total titratable acidity of $0.73 \%$, total soluble solids of $9.12^{\circ}$ Brix and a pH value of 3.33 (CARDOSO et al., 2011).

Despite the great potential of these fruits, only the native people consume araticum and cagaita as fresh fruit or in juices, ice cream, cakes, sweets, jellies and jams (ARRUDA et al., 2015; ARRUDA et al., 2016). The limited consumption of these fruits is partly due to scarce information regarding their potential uses, and the processing and quality of the processed foods obtained from araticum and cagaita. In order to overcome this limitation, this study aimed to use the Brazilian Savannah fruits araticum and cagaita in the formulation of products, and evaluate their sensory acceptance by children aged 7-9 years from a school in the municipality of Rio Paranaíba (MG/Brazil).

\section{Materials and methods}

\subsection{Obtaining the fruit and pulp}

The araticum and cagaita fruits were manually collected in regions near the city of Rio Paranaíba (MG/Brazil), respecting their respective seasonality. The araticum fruits were harvested in March 2014, while the cagaita fruits were harvested between October and November of the same year. The morphologically perfect and completely mature fruits were washed with tap water to remove surface dirt, sanitized by immersion for 10 minutes in a $100 \mathrm{ppm}$ sodium hypochlorite solution, and rinsed again. The pulps were obtained from the peeled (except cagaita) and pitted fruits, packed into polyethylene bags $(100 \mathrm{~g})$ to reduce contact with the air, and immediately stored at $-18{ }^{\circ} \mathrm{C}$ until used.

\subsection{Product development}

\subsubsection{Milk caramels containing araticum pulp}

Three formulations of milk caramels were developed: DP (standard: no added araticum pulp), DA (with added araticum pulp) and DB (with added araticum pulp and grated coconut), as shown in Table 1. 
Development and sensory evaluation of products containing the Brazilian Savannah fruits araticum (Annona crassiflora Mart.) and cagaita (Eugenia dysenterica Mart.)

Arruda, H. S. et al.

All the ingredients were mixed manually until obtaining a homogenous mixture. The mixture obtained was concentrated in stainless steel containers with manual stirring, using a semi-industrial stove. On reaching the proper consistency (for a solid consistency after cooling), the heat source was turned off and stirring continued until hardening of the mixture. The mixture was then poured into moulds and cut into $2 \mathrm{~cm}^{2}$ cubes. After cooling they were stored in coded plastic containers and stored at room temperature until the sensory analysis.

\subsubsection{Cagaita refreshers}

Three formulations of refresher containing cagaita pulp were developed: RP (standard: cagaita pulp), RA (cagaita pulp and orange juice) and RB (cagaita pulp and carrot juice), as described in Table 2.

The carrot juice was obtained as follows: washing, sanitizing (100 ppm sodium hypochlorite for 10 minutes), peeling, cutting, formulation (for each $400 \mathrm{~g}$ of chopped carrots $200 \mathrm{~mL}$ of added water), trituration in a blender for 2 minutes and separation of the solids by passing through a fine mesh cloth (voil - 100\% polyester), used for pressing foods. The whole orange juice was obtained by manually peeling and pulping the oranges. The refreshers were obtained by mixing the ingredients in the proportions shown in Table 2, and storing in a refrigerator at approximately $5{ }^{\circ} \mathrm{C}$ until completion of the sensory analysis.

\subsubsection{Cagaita jam}

Cagaita jam was prepared according to Santos et al. (2012). Initially, the cagaita pulp (800 g) and sugar (545 g) were mixed while stirring and the mixture then heated

Table 1. Ingredients used in the formulation of the milk caramels.

\begin{tabular}{lccr}
\multicolumn{1}{c}{ Ingredients } & DP & DA & DB \\
Milk (L) & 2.0 & 2.0 & 2.0 \\
Sugar $(\mathrm{g})$ & 500.0 & 500.0 & 500.0 \\
Araticum pulp $(\mathrm{g})$ & - & 500.0 & 500.0 \\
Grated coconut $(\mathrm{g})$ & - & - & 200.0 \\
Sodium bicarbonate $(\mathrm{g})$ & 5.0 & 5.0 & 5.0 \\
\hline
\end{tabular}

DP (standard: no added araticum pulp); DA (with added araticum pulp) and DB (with added araticum pulp and grated coconut).

Table 2. Ingredients used in the formulation of the cagaita refreshers.

\begin{tabular}{lcrc}
\multicolumn{1}{c}{ Ingredients } & RP & RA & RB \\
Water $(\mathrm{L})$ & 2.5 & 2.0 & 2.0 \\
Cagaita pulp $(\mathrm{kg})$ & 1.0 & 1.0 & 1.0 \\
Sugar $(\mathrm{g})$ & 350.0 & 350.0 & 350.0 \\
Orange juice $(\mathrm{L})$ & - & 0.5 & - \\
Carrot juice $(\mathrm{L})$ & - & - & 0.5 \\
\hline
\end{tabular}

RP (standard: cagaita pulp); RA (cagaita pulp and orange juice) and RB (cagaita pulp and carrot juice). to $100{ }^{\circ} \mathrm{C}$. The heat source was then turned off and the dissolved pectin ( $5 \mathrm{~g}$ dissolved in hot water) added. Stirring continued for about 2 minutes to homogenize the mixture and the heat source then switched back on and the mixture cooked to a final soluble solids concentration of $67^{\circ}$ Brix, measured using a pocket refractometer. Cooking was done in a stainless steel container with manual agitation on a semi-industrial stove. After processing, glass bottles previously sterilized at $121^{\circ} \mathrm{C}$ for 15 minutes were hot filled with jam, closed with a metal lid, immediately cooled by immersion in cold water for 15 minutes, and stored at room temperature until the time of analysis.

\subsection{Sensory analysis}

The project was approved by the Ethics Committee of the University Centre of Patos de Minas (Unipam), Protocol 55/10, and all participants signed Informed Consent Forms (ICM).

The study was carried out with children aged between 7 years and 9 years and 11 months at the State School 'Professor José Luiz de Araújo' in the municipality of Rio Paranaíba (MG/Brazil). 190 children took part in the sensory evaluation of the milk caramels containing araticum pulp; 84 boys (44.21\%) and 106 girls (55.79\%), whereas the cagaita refresher sensory tests involved 162 children, of which 67 were boys (41.36\%) and 95 girls (58.64\%). A total of 151 children took part in the sensory tests with the cagaita jam, 62 boys (41.06\%) and 89 girls (58.94\%).

The sensory analyses of the products were carried out in the morning and in the afternoon in appropriate rooms kindly provided by the aforementioned school. The acceptability of the products was evaluated using a 7-point facial hedonic scale. The children were directed to an appropriate room where they received the samples of milk caramels with and without araticum pulp (formulations DP, DA and DB) of approximately $2 \mathrm{~cm}^{2}$, which were presented on plastic plates; the cagaita refresher samples (formulations RP, RA and RB) were offered in $50 \mathrm{~mL}$ disposable cups; and the samples of cagaita jam, offered together with a cracker, served on a plastic dish. All samples were properly coded with three digit numbers (REIS; MINIM, 2010). The samples of milk caramels, cagaita refresher and cagaita jam were presented randomly in a monadic way (STONE; SIDEL, 1993) always accompanied by a disposable cup with $50 \mathrm{~mL}$ of filtered water at room temperature for cleansing the palate, in order to ensure adequate perception of the sensory aspects of each sample product evaluated. A numerical value was assigned for each illustration on the hedonic scale: the picture corresponding to a facial expression of "dislike extremely" was assigned the numerical value of 1, while the picture corresponding to the facial expression "like extremely" was assigned the value 7 . The acceptability 
Development and sensory evaluation of products containing the Brazilian Savannah fruits araticum (Annona crassiflora Mart.) and cagaita (Eugenia dysenterica Mart.)

Arruda, H. S. et al.

index (AI) was calculated using Equation 1 as shown below (CASTRO et al., 2007):

$$
\mathrm{Al}(\%)=\frac{100 \times(\text { Average score obtained for the product })}{\text { Highest score given to the product }}
$$

\subsection{Statistical analysis}

The acceptance test data were evaluated by an analysis of variance (ANOVA), followed by Tukey's test in the case of significant difference. The Student t test was used to assess whether there were differences according to gender in acceptance of the products. All tests were done at $5 \%$ of probability $(p \leq 0.05)$.

\section{Results and discussion}

It is important to stimulate the intake of fruits and vegetables in young children (NEDERKOORN et al., 2015). Studies with the fruits of the Savannah are recent, and only a few scientific publications on the development and sensory evaluation of products containing araticum and cagaita fruit pulps can be found, which restricts the comparison between the present results and those of other studies. Thus, the results of this study were compared with products developed from araticum and cagaita and also from other Savannah and/or exotic fruits found in the literature.

The mean scores for the sensory evaluation and acceptability index of the milk caramels according to gender are shown in Table 3.

There was no statistical difference ( $p>0.05)$ between genders regarding the sensory acceptance of any of the milk caramel samples evaluated. Significant difference was not observed ( $p>0.05$ ) between the formulations of milk caramels (DP, DA and DB) regarding acceptance by both genders and also in general. The average acceptance scores for the milk caramels were between the terms "like moderately" and "like very much" on the 7-point facial hedonic scale. Good sensory acceptance of the products by children who were potential consumers of the sweets was verified. A product can be considered as accepted in sensory terms, when it has an acceptability index greater than $70 \%$ (CASTRO et al., 2007). From the evaluation of this index, it can be seen that the samples of milk caramels were well accepted. According to Mesquita et al. (2007) and Morzelle et al. (2011), araticum is highly appreciated due to its sweet yellowish pulp, and its intense aroma.

Similar results were obtained by Villela et al. (2013) when evaluating formulations of bread with the addition of different amounts of araticum flour (10 and 20\%). These authors noted that the formulations were well-accepted and did not differ statistically from the control formulation. The mean scores ranged between 4.03 and 4.11 (comparable to "I liked" and "I liked very much" on the 5-point hedonic scale) in the acceptance test, and reached 80.60 to $82.20 \%$ on the acceptability index.

Snack bars containing increasing amounts of araticum flour (5 to $20 \%$, expressed in w/w) were produced and a sensory analysis carried out by Silva et al. (2014). The mean score for the sensory descriptors (appearance, aroma, taste, texture, overall acceptance) was 7 (comparable to "liked moderately" on the 9-point hedonic scale), slightly superior to the control bar category and similar to those obtained for the formulations of milk caramels. In addition, the authors found that the addition of up to $10 \%$ of araticum flour significantly improved the taste of the snack bars. Moreover, Morzelle et al. (2012) noted an indifferent behaviour from potential consumers regarding the attribute of flavour (mean score of 3.30 on the 5-point hedonic scale) and purchase intent (mean score of 3.01 on the 5-point hedonic scale) for ice cream formulated with araticum pulp.

On evaluating the acceptance of araticum yogurts with respect to their flavour, Oliveira et al. (2008) observed that, with the exception of the formulation with $50 \%$ araticum pulp (mean score of 5.60), the other experimental yogurt formulations (with 12.5 and $25 \%$ araticum pulp) did not differ from the standard formulation (without pulp), and these formulations had mean scores between 6.00 and 7.00, equivalent to the terms "like slightly" and "like moderately" on the 9-point hedonic scale. Lucia et al. (2012) also showed higher acceptability means for yogurt formulations with the addition of 20 or $30 \%$ araticum pulp with scores between 6 ("liked slightly") and 8 ("liked very much").

Morzelle et al. (2011) observed high acceptance levels for mixed nectars of araticum and passion fruit, and the nectars with 50 and $70 \%$ araticum pulp showed an average acceptability of 7.94 and 8.00 , respectively,

Table 3. Mean scores for the sensory evaluation and acceptability index of milk caramels according to gender.

\begin{tabular}{|c|c|c|c|c|c|c|}
\hline \multirow{2}{*}{ Sample } & \multicolumn{3}{|c|}{ Acceptance Test } & \multicolumn{3}{|c|}{ Acceptability Index (\%) } \\
\hline & Male & Female & Overall & Male & Female & Overall \\
\hline DP & $5.73 \pm 1.33^{\mathrm{Aa}}$ & $5.73 \pm 1.26^{\mathrm{Aa}}$ & $5.73 \pm 1.29^{A}$ & 81.86 & 81.86 & 81.86 \\
\hline DA & $5.65 \pm 1.38^{\mathrm{Aa}}$ & $5.72 \pm 1.29^{\mathrm{Aa}}$ & $5.69 \pm 1.33^{\mathrm{A}}$ & 80.71 & 81.71 & 81.29 \\
\hline DB & $5.46 \pm 1.43^{\mathrm{Aa}}$ & $5.81 \pm 1.33^{\mathrm{Aa}}$ & $5.66 \pm 1.39^{A}$ & 78.00 & 83.00 & 80.86 \\
\hline
\end{tabular}

Different upper case letters in the same column indicate significant difference between the formulations at $5 \%$ probability according to the Tukey's test. Different lower case letters in the same row indicate difference in acceptance regarding gender at $5 \%$ probability according to the Student $t$ test. DP (standard: no added araticum pulp); DA (with added araticum pulp) and DB (with added araticum pulp and grated coconut). 
Development and sensory evaluation of products containing the Brazilian Savannah fruits araticum (Annona crassiflora Mart.) and cagaita (Eugenia dysenterica Mart.)

Arruda, H. S. et al.

scores in the category of "like very much" on the 9-point hedonic scale.

Table 4 presents the mean scores for the sensory evaluation and acceptability indexes of the cagaita refreshers according to gender.

The cagaita refreshers analysed were equally accepted ( $p>0.05$ ) by both genders. However, the cagaita refresher containing orange juice (RA) was more accepted $(p<0.05)$ than the other formulations (RP and RB) by both genders and in general. The average acceptance scores for the cagaita refresher with orange juice (RA) were between "like very much" and "like extremely" on the 7-point facial hedonic scale, while for the standard cagaita refresher (RP) and that with carrot juice (RB) the scores were between "like moderately" and "like very much", verifying the sensory acceptance of the products by the children, especially with respect to the beverage with orange juice. A previous study carried out by Arruda et al. (2015) showed that the cagaita fruits were highly appreciated by children.

It can be observed that the cagaita refresher with orange juice showed the highest acceptability index; the values found for boys, girls and overall were 95.29\%, $90.86 \%$ and $92.71 \%$, respectively. A similar result was found by Torregrosa et al. (2006), who observed that the combination of orange juice with carrot improved the acceptance of the product compared to carrot juice alone. The fact that orange juice is the most well-known juice amongst children, since the juice and the fruit itself are widely marketed in Rio Paranaíba, may be related to the greater acceptance of the cagaita refresher with added orange juice. According to Branco et al. (2007), despite the great diversity of industrialised fruit juices available in Brazil, what stands out most is orange juice, due to its well-known taste, wide acceptability and availability. Although the cagaita refresher with orange juice received the highest sensory acceptance score, it was noted that the formulation containing only cagaita pulp had an acceptability index above $70 \%$, demonstrating that the provision of a refresher containing only cagaita pulp could be commercially promising.

When assessing the acceptability of yogurts flavoured with Savannah fruits, Rocha et al. (2008) observed that araticum and cagaita flavoured yogurts were well accepted by consumers. The araticum yogurt showed an average score of 7.40, between "I would eat it often" and "I would eat it very often", while the average score of the cagaita yogurt was 7.00, corresponding to "I would eat it often".

Assumpção et al. (2013) also found high scores for acceptability (7.51 and 7.96) and purchase intent (4.12 and 4.43) for mixed cagaita and mangaba nectars. The mean acceptability of the products was "like very much" on the 9-point hedonic scale, whereas the scores for purchase intent were between "would probably buy" and "would definitely buy", according to the 5-point hedonic scale.

Morzelle et al. (2009) found similar levels of acceptance for mixed sugar apple (Annona squamosa L.) and passion fruit nectars, in agreement with those found for the refreshers developed and evaluated in the present study. The nectars with 50 and $70 \%$ sugar apple pulp had an average acceptability of 8.00 , in the category of "like very much" on the 9-point hedonic scale.

The mean sensory evaluation and acceptability index scores for the cagaita jam according to gender are shown in Table 5.

There was no significant difference $(p>0.05)$ in sensory acceptance for the cagaita jam between the boys and the girls. The average scores in the acceptance test for cagaita jam were between "like moderately" and "like very much" on the 7-point facial hedonic scale. It was observed that the cagaita jam was well accepted according to the acceptability index, since it presented an index above 70\% for both sexes and in general (CASTRO et al., 2007). Similar results were found by Santos et al. (2012) who, when evaluating the sensory characteristics of cagaita

Table 4. Mean scores for the sensory evaluation and acceptability indexes of cagaita refreshers according to gender.

\begin{tabular}{|c|c|c|c|c|c|c|}
\hline \multirow{2}{*}{ Sample } & \multicolumn{3}{|c|}{ Acceptance Test } & \multicolumn{3}{|c|}{ Acceptability Index (\%) } \\
\hline & Male & Female & Overall & Male & Female & Overall \\
\hline $\mathrm{RP}$ & $5.70 \pm 1.72^{\mathrm{Ba}}$ & $5.71 \pm 1.64^{\mathrm{Ba}}$ & $5.70 \pm 1.67^{\mathrm{B}}$ & 81.43 & 81.57 & 81.43 \\
\hline RA & $6.67 \pm 0.90^{\mathrm{Aa}}$ & $6.36 \pm 1.15^{\mathrm{Aa}}$ & $6.49 \pm 1.07^{\mathrm{A}}$ & 95.29 & 90.86 & 92.71 \\
\hline $\mathrm{RB}$ & $5.81 \pm 1.69^{\mathrm{Ba}}$ & $5.38 \pm 1.74^{\mathrm{Ba}}$ & $5.56 \pm 1.73^{\mathrm{B}}$ & 83.00 & 76.86 & 79.43 \\
\hline
\end{tabular}

Different upper case letters in the same column indicate significant difference between the formulations at $5 \%$ probability according to the Tukey test. Different lower case letters in the same row indicate difference in acceptance regarding gender at $5 \%$ probability according to the Student t test. RP (standard: cagaita pulp); RA (cagaita pulp and orange juice) and RB (cagaita pulp and carrot juice).

Table 5. Mean scores for the sensory evaluation and acceptability index of cagaita jam according to gender.

\begin{tabular}{|c|c|c|c|c|c|c|}
\hline \multirow{2}{*}{ Sample } & \multicolumn{3}{|c|}{ Acceptance Test } & \multicolumn{3}{|c|}{ Acceptability Index (\%) } \\
\hline & Male & Female & Overall & Male & Female & Overall \\
\hline Cagaita Jam & $5.60 \pm 1.98^{a}$ & $5.94 \pm 1.55^{a}$ & $5.80 \pm 1.75$ & 80.00 & 84.86 & 82.86 \\
\hline
\end{tabular}


Development and sensory evaluation of products containing the Brazilian Savannah fruits araticum (Annona crassiflora Mart.) and cagaita (Eugenia dysenterica Mart.)

Arruda, H. S. et al.

jams noted they were accepted for the attribute of flavour with average scores between 7.60 and 7.99 , equivalent to the hedonic terms "like moderately" and "like very much". Lago-Vanzela et al. (2011) found satisfactory acceptance of peel and pulp caja-manga jams, with mean scores of 7.19 and 6.49, respectively, between the hedonic terms of "like slightly" and "like very much". A similar result was observed by Lago et al. (2006) working with jambolan jam, who found an average score of acceptance for flavour equal to 7 .

Among all the products developed, the cagaita refresher with orange juice showed the greatest sensory acceptance score, since it showed the highest acceptability index (95.29\% for boys and $90.86 \%$ for girls) and the average scores in the acceptance test for both genders were between the terms "like very much" and "like extremely" on the 7-point scale. On the other hand, the other products (the three formulations of milk caramels, the other cagaita refresher formulations and the cagaita jam formulation) showed lower acceptability indexes (between 76.86 and $84.86 \%$ ), the average acceptance scores for the products being situated between the categories of "like moderately" and "like very much". Thus, the cagaita refresher with orange juice showed the best potential for insertion onto the food market.

\section{Conclusions}

There was no influence of gender on the sensory acceptance of any of the products evaluated (milk caramels, refreshers and cagaita jam). Regarding sensory acceptance, it was found that the three formulations of milk caramels were equally accepted, whereas the cagaita refresher with orange juice was more accepted than the others. Moreover, all the products developed were well accepted by the group of children, showing that these products proved to be attractive due to their sensory characteristics, presenting technological potential, especially when related to the aspect of adding value to products from the Savannah. Thus all these formulations could be placed on the market as products for children with prospects for success, due to the good acceptance by those consumers.

\section{Acknowledgements}

The authors would like to thank the State School 'Professor José Luiz de Araújo' for their partnership, and also the families, children and teachers involved in the project.

\section{References}

ARRUDA, H. S.; ALMEIDA, M. E. F. Frutos do cerrado: panorama, resgate cultural e aproveitamento culinário. Saarbrücken: Novas Edições Acadêmicas, 2015. 132 p.
ARRUDA, H. S.; CRUZ, R. G.; ALMEIDA, M. E. F. Caracterização química, funcionalidade e toxicidade do pequi. Nutrição Brasil, São Paulo, v. 11, n. 5, p. 315-319, 2012.

ARRUDA, H. S.; FERNANDES, R. V. B.; BOTREL, D. A.; ALMEIDA, M. E. F. Frutos do Cerrado: conhecimento e aceitação de Annona crassiflora Mart. (Araticum) e Eugenia dysenterica Mart. (Cagaita) por crianças utilizando o paladar e a visão. Journal of Health and Biological Sciences, Fortaleza, v. 3, n. 4, p. 224-230, 2015. http://dx.doi.org/10.12662/2317-3076jhbs.v3i4.168.p224-230.2015.

ARRUDA, H. S.; PEREIRA, G. A.; PASTORE, G. M. Oligosaccharide profile in Brazilian Cerrado fruit araticum (Annona crassiflora Mart.). LWT - Food Science and Technology, Berlin, 2016. http://dx.doi.org/10.1016/j.Iwt.2016.05.017.

ASSUMPÇÃO, C. F.; BACHIEGA, P.; SANTANA, A. T. M. C.; MORZELLE, M. C.; VILAS BOAS, B. M.; SOUZA, E. C. Néctar misto de mangaba (Hancoria speciosa Gomes) e cagaita (Eugenia dysenterica): perfil sensorial e características físico-químicas. Revista Brasileira de Produtos Agroindustriais, Campina Grande, v. 15, n. 3, p. 219-224, 2013.

BRANCO, I. G.; SANJINEZ-ARGANDOÑA, E. J.; SILVA, M. M.; PAULA, T. M. Avaliação sensorial e estabilidade físico-química de um blend de laranja e cenoura. Ciência e Tecnologia de Alimentos, Campinas, v. 27, n. 1, p. 7-12, 2007. http://dx.doi. org/10.1590/S0101-20612007000100002.

CAMPOS, R. P.; HIANE, P. A.; RAMOS, M. I. L.; RAMOS FILHO, M. M.; MACEDO, M. L. R. Conservação pós-colheita de guavira (Campomanesia sp.). Revista Brasileira de Fruticultura, Jaboticabal, v. 34, n. 1, p. 41-49, 2012. http://dx.doi.org/10.1590/ S0100-29452012000100008.

CARDOSO, L. M.; MARTINO, H. S. D.; MOREIRA, A. V. B.; RIBEIRO, S. M. R.; PINHEIRO-SANT'ANA, H. M. Cagaita (Eugenia dysenterica DC.) of the Cerrado of Minas Gerais, Brazil: physical and chemical characterization, carotenoids and vitamins. Food Research International, Oxford, v. 44, n. 7, p. 2151-2154, 2011. http://dx.doi.org/10.1016/j.foodres.2011.03.005.

CARDOSO, L. M.; OLIVEIRA, D. S.; BEDETTI, S. F.; MARTINO, H. S. D.; PINHEIRO-SANT'ANA, H. M. Araticum (Annona crassiflora Mart.) from the Brazilian Cerrado: chemical composition and bioactive compounds. Fruits, Paris, v. 68, n. 2, p. 121-134, 2013. http://dx.doi.org/10.1051/fruits/2013058.

CASTRO, L. Í. A.; REAL, C. M. V.; PIRES, I. S. C.; PIRES, C. V.; PINTO, N. A. V. D.; MIRANDA, L. S.; ROSA, B. C.; DIAS, P. A. Quinoa (Chenopodium quinoa Willd): digestibilidade in vitro, desenvolvimento e análise sensorial de preparações destinadas a pacientes celíacos. Alimentos e Nutrição, Araraquara, v. 18, n. 4, p. 413-419, 2007.

FINCO, F. D. B. A.; SILVA, I. G.; OLIVEIRA, R. B. Physicochemical characteristics and antioxidant activity of three native fruits from Brazilian Savannah (Cerrado). Alimentos e Nutrição, Araraquara, v. 23, n. 2, p. 179-185, 2012. 
Development and sensory evaluation of products containing the Brazilian Savannah fruits araticum (Annona crassiflora Mart.) and cagaita (Eugenia dysenterica Mart.)

Arruda, H. S. et al.

LAGO, E. S.; GOMES, E.; SILVA, R. Produção de geléia de jambolão (Syzygium cumini Lamarck): processamento, parâmetros físico-químicos e avaliação sensorial. Ciência e Tecnologia de Alimentos, Campinas, v. 26, n. 4, p. 847-852, 2006. http://dx.doi. org/10.1590/S0101-20612006000400021.

LAGO-VANZELA, E. S.; RAMIN, P.; UMSZA-GUEZ, M. A.; SANTOS, G. V.; GOMES, E.; SILVA, R. Chemical and sensory characteristics of pulp and peel 'cajá-manga' (Spondias cytherea Sonn.) jelly. Ciência e Tecnologia de Alimentos, Campinas, v. 31, n. 2, p. 398-405, 2011. http://dx.doi.org/10.1590/S010120612011000200018

LUCIA, F. D.; FERREIRA, E. B.; SANTOS, R. C.; MOREIRA, M. A. M.; CORRÊA, S. C.; VILAS BOAS, E. V. Acceptability of yoghurt with marolo pulp (Annona crassiflora Mart.) in the traditional and diet/light formulations. Revista da Universidade Vale do Rio Verde, Três Corações, v. 10, n. 2, p. 85-92, 2012. http://dx.doi. org/10.5892/ruvrv.2012.102.8592.

MESQUITA, M. A. M.; NAVES, R. V.; SOUZA, E. R. B.; BERNARDES, T. G.; SILVA, L. B. Caracterização de ambientes com alta ocorrência natural de araticum (Annona crassiflora Mart.) no Estado de Goiás. Revista Brasileira de Fruticultura, Jaboticabal, v. 29, n. 1, p. 15-19, 2007. http://dx.doi.org/10.1590/S010029452007000100006.

MORZELLE, M. C.; LAMOUNIER, M. L.; SOUZA, E. C.; SALGADO, J. M.; VILAS-BOAS, E. V. B. Caracterização físico-química e sensorial de sorvetes à base de frutos do cerrado. Revista do Instituto de Laticínios Cândido Tostes, Juiz de Fora, v. 67, n. 387 , p. 70-78, 2012. http://dx.doi.org/10.5935/2238-6416.20120052.

MORZELLE, M. C.; SOUZA, E. C.; ASSUMPÇÃO, C. F.; FLORES, J. C. J.; OLIVEIRA, K. A. M. Agregação de valor a frutos de ata através do desenvolvimento de néctar misto de maracujá (Passiflora edulis Sims) e ata (Annona squamosa L.). Alimentos e Nutrição, Araraquara, v. 20, n. 3, p. 389-393, 2009.

MORZELLE, M. C.; SOUZA, E. C.; ASSUMPÇÃO, C. F.; VILAS BOAS, B. M. Desenvolvimento e avaliação sensorial de néctar misto de maracujá (Passiflora edulis Sims) e araticum (Annona crassiflora). Revista Brasileira de Produtos Agroindustriais, Campina Grande, v. 13, n. 2, p. 131-135, 2011.

NEDERKOORN, C.; JANSEN, A.; HAVERMANS, R. C. Feel your food: the influence of tactile sensitivity on picky eating in children. Appetite, London, v. 84, p. 7-10, 2015. http://dx.doi. org/10.1016/j.appet.2014.09.014. PMid:25261102.

OLIVEIRA, K. A. M.; RIBEIRO, L. S.; OLIVEIRA, G. V.; PEREIRA, J. M. A. T. K.; MENDONÇA, R. C. S.; ASSUMPÇÃO, C. F. Desenvolvimento de formulação de iogurte de araticum e estudo da aceitação sensorial. Alimentos e Nutrição, Araraquara, v. 19, n. 3, p. 277-281, 2008.

QUEIROZ, S. É. E. Estudos moleculares em Annona crassiflora Mart. Revista de Biologia e Ciências da Terra, Campina Grande, v. 11, n. 2, p. 23-29, 2011

REIS, R. C.; MINIM, V. P. R. Teste de aceitação. In: MINIM, V. P. R. (Ed.). Análise sensorial: estudos com consumidores. 2. ed. Viçosa: Editora UFV, 2010. p. 66-82.

ROCHA, C.; COBUCCI, R. M. A.; MAITAN, V. R.; SILVA, O. C. Elaboração e avaliação de iogurte sabor frutos do cerrado. Boletim do Centro de Pesquisa de Processamento de Alimentos, Curitiba, v. 26, n. 2, p. 255-266, 2008. http://dx.doi. org/10.5380/cep.v26i2.13280.

SANTOS, P. R. G.; CARDOSO, L. M.; BEDETTI, S F.; HAMACEK, F. R.; MOREIRA, A. V. B.; MARTINO, H. S. D.; PINHEIROSANT'ANA, H. M. Geleia de cagaita (Eugenia dysenterica DC.): desenvolvimento, caracterização microbiológica, sensorial, química e estudo da estabilidade. Revista do Instituto Adolfo Lutz, São Paulo, v. 71, n. 2, p. 281-290, 2012.

SILVA, E. P.; SIQUEIRA, H. H.; LAGO, R. C.; ROSELL, C. M.; VILAS BOAS, E. V. B. Developing fruit-based nutritious snack bars. Journal of the Science of Food and Agriculture, Hoboken, v. 94, n. 1, p. 52-56, 2014. http://dx.doi.org/10.1002/jsfa.6282. PMid:23794383.

SILVA, M. R.; LACERDA, D. B. C. L.; SANTOS, G. G.; MARTINS, D. M. O. Caracterização química de frutos nativos do cerrado. Ciência Rural, Santa Maria, v. 38, n. 6, p. 1790-1793, 2008 a. http://dx.doi.org/10.1590/S0103-84782008000600051.

SILVA, M. R.; SANTOS JÚNIOR, R. T. O.; FERREIRA, C. C. C. Estabilidade da vitamina $\mathrm{C}$ em cagaita in natura e durante a estocagem da polpa e refresco. Pesquisa Agropecuária Tropical, Goiânia, v. 38, n. 1, p. 53-58, 2008b. http://dx.doi. org/10.5216/pat.v38i1.3628.

STONE, H.; SIDEL, J. Sensory evaluation practices. 2. ed. New York: Academic Press, 1993. 338 p.

tORREGROSA, F.; ESTEVE, M. J.; FRÍGOLA, A.; CORTÉS, C. Ascorbic acid stability during refrigerated storage of orangecarrot juice treated by high pulsed electric field and comparison with pasteurized juice. Journal of Food Engineering, Oxford, v. 73, n. 4, p. 339-345, 2006. http://dx.doi.org/10.1016/j. jfoodeng.2005.01.034.

VILLELA, P.; BATISTA, Â. G.; DESSIMONI-PINTO, N. A. V. Nutritional composition of Annona crassiflora pulp and acceptability of bakery products prepared with its flour. Ciência e Tecnologia de Alimentos, Campinas, v. 33, n. 3, p. 417-423, 2013. http:// dx.doi.org/10.1590/S0101-20612013005000082. 